\title{
A Study on Influencing Factors and Countermeasures of College Students' Burnout in Physical Training
}

\author{
Han Jinzhu ${ }^{1, a}$ \\ ${ }^{1}$ Department of Military and Physical Education, Jilin Agricultural University, Changchun City, \\ Jilin Province, 130118, China
}

Keywords: College students; Physical education; Physical training; Burnout; Influencing factors; Countermeasures

\begin{abstract}
Physical training burnout refers to a series of students' negative psychology and behavior in physical training caused by personal factors and environmental factors. Based on the author's study and practical experience, this paper first summarized the causes of college students' physical training burnout, and then put forward relevant countermeasures. This article not only has an important significance in improving the theory of physical training burnout, but also can provide reference for deepening the reform of college education and improving the learning situation of college students with physical education major.
\end{abstract}

\section{Introduction}

Although the study of burnout began in the mid-1970s, the study of burnout was mainly in the occupational field which aims at assisting professional workers. However, there is few research on students' learning burnout. The study of burnout of college students with physical education major is a blank field. With the enrollment expansion of colleges and universities, the number of college students with physical education major also increases. This paper analyzed the causes of college students' physical training burnout, and finally put forward the corresponding countermeasures and suggestions, which aims at providing some theoretical reference for solving college students' burnout in physical education.

\section{The Influencing Factors of College Students' Physical Training Burnout}

\subsection{Social cause}

Affected by the traditional concept, the public in China generally accept the examination-oriented education model and psychology which triggers by this model. People attach importance to the general knowledge course and neglect physical education in the current society. The universal values have a profound and significant influence on college students' ideology. In order to reasonably connect with the universal value in thought and behavior, and adopt to social survival rules formed by this social cognition, students in middle school and even in primary school have always focused on cultural lessons and ignored physical training. When they enter the university, it is difficult for them to change this kind of psychology which has been sustained in their mind for a long time. Moreover, the assessment standard for talents does not include the sports-related quality assessment in the current social employment. In the severe employment situation, students will just train and improve their quality in accordance with the standards of personnel assessment. Therefore, when college students take physical exercise, they cannot recognize the beneficial effect of physical training on their health, and they even complain that physical training occupies their valuable time. This deep-seated social factor further contributes to college students' physical training burnout. If we do not change the social cognition, results of all reforms which aim at improving the teaching 
effect of physical training can not be realized.

\subsection{School cause}

The effective promotion of university education is a great way to test the height and depth of students' self-awareness. If students can not realize the beneficial effect of physical training on their physical health, students will naturally reduce their desire and enthusiasm in participating in physical training. Therefore, students need the guidance from the school and teachers to make them realize the fun of physical training and the positive impact of physical training. However, a vast majority of colleges and universities ignore the fun in physical education and training, and neglect the strict requirements on students. Now, the form of college physical education and training is relatively simple. Students have experienced dull physical education and training in primary school, junior high school and high school, and they expect to have more professional and interesting physical education in the university, but the university disappoints them. Due to the faster updating of sports facilities in the university, the existing facilities cannot meet students' training needs; because of the enrollment expansion in recent years, school playground becomes more and more crowded; sports teacher in university do not manage students strictly and they do not have the appropriate and rational attitude to students' late arrival and early leave, which allows students to lost their sense of awe for participating in physical training. The above phenomena still exist in most colleges and universities and the fault in this physical education and training environment is the main factor of college students' burnout. If the school does not make the corresponding change, college students will always have burnout in physical training.

\subsection{Individual cause}

Before college students enter the university, the physical education they received usually lack professionalism. Because the secondary schools do not attach importance to physical education, cultural classes often occupy the time of physical education and students' opportunity for getting physical training is been deprived, which makes the physical quality of many college students is poor. Obesity, the lack of endurance and lack of explosive ability have become the true portrayal of today's college students. They do not have good physical education before entering colleges. Therefore, in the physical education and training, in order to avoid awkwardness, college students will try to reduce their participation in physical training or express their impatience to end the training as soon as possible in physical education which they have to participate in. As a result, they always get through the physical training carelessly. College students do not attach importance to physical training and they lack self-confidence in their own sports quality. This not only affects the teaching effect of physical training and education, but also makes the physical quality of college students continue to decline in the long term, which will affect the future of an era.

\section{The Countermeasures of College Students' Physical Training Burnout}

\subsection{To strengthen health education and improve college students' understanding of physical training}

In order to change college students' improper cognition of physical training, to improve students' participation in physical training and to dispel their burnout in physical training, the school should actively strengthen health education, so that college students can realize that physical training has an important influence on improving their physical quality. Furthermore, they should make students aware of the importance of good health for their future life and learning. Therefore, schools can carry out campus activities about health education. Colleges can use posters and sports activities to attract students to participate in physical training. In 
addition, with many hot sports-related variety shows broadcasting, the school can make use of the great influence of variety shows to organize teachers and students to participate the "tear brand" campaign. The participation by all people and the expansion of health education publicity can deepen college students' understanding of the health education and reduce their physical training burnout.

\subsection{To create a good physical education environment and stimulate college students' learning interest in physical training}

The construction of a good physical training environment in the university has an important influence on the promotion of college students' participation in physical training. Therefore, the school should try to realize the professional and scientific construction of the physical education environment, so that students can have the desire to participate in physical education when stimulated by the professional physical training environment. For example, because the playground is crowded, the school can extend the playground and build professional plastic runway and lawn for students, so as to enhance their training experience; for old sports facilities, colleges should dismantle them and introduce new types of physical exercise equipment, which not only protects students' physical safety in physical training, but also stimulates their participation enthusiasm.

\subsection{To improve the traditional physical education model}

In the traditional physical education model, the single and dull teaching has become an important factor that influences students' physical raining experience. Therefore, it is necessary to reorganize physical education. First of all, teachers should take the responsibility to make students take physical education and training, so that students can recognize the necessity and importance of participation in physical training. Teachers also should tell students the corresponding punishment if they do not follow the physical training norms. They should not relax themselves in the teaching. Second, in the physical training, teachers can use some modern electronic products to conduct classroom teaching demonstration to attract students' interest in participating in the training. For example, teachers can use the sports bracelet, so that students can know their own physical changes in the movement. This also allows students to understand professional sports knowledge related to the physical function, which will not cause students' weariness. On the contrary, students are eager to know whether their physical function is normal and they will have a strong desire to learn. Finally, in the teaching evaluation for students, teachers should make reasonable and accurate judgments based on the physical quality of different students and then provide students with incentive language-based teaching evaluation, so as to stimulate students' self-confidence and reduce their burnout .

\subsection{To connect the school education, social education, family education actively}

The development of college students' physical training burnout is a result of the combination of social factors, family factors and school factors. Therefore, it is necessary to combine school, society and family together to reduce college students' burnout in physical training. For example, schools can use their own resources to organize a marathon competition which college students and their parents can participate in, and invite the social media to report this competition. The extensive participation of college students and parents can change their negative feelings of physical training. The extensive social media coverage can spark topics related to college physical training in the community, so that the public awareness of physical fitness can become an important assessment standard for college students. Then, the social recruitment of talents will increase the assessment of the physical quality, thus stimulating college students' enthusiasm in participating in physical training. 


\section{Conclusion}

College students' burnout in physical education and training has become a serious problem in the current physical teaching. Many factors cause this problem, including the social factor, school factor, family factor and individual factor. Therefore, in order to change students' attitude to physical training, we need to carry out reform in the society, school, family and individual, such as the institution and model changes, so as to reduce the college students' burnout. As an important driving force of social development in China, students' physical condition not only influences personal development, but also affects the development of the whole country. Therefore, college students' burnout in physical training should get great attention to meet the needs of times.

\section{References}

[1] Sun Min. A Study on College Students' Burnout in Physical Education and Training [J]. Guide to Business, 2016, (07): 175-176.

[2] Liu Zhenguo. An Analysis of Influencing Factors and Countermeasures of the Physical Training in Colleges and Universities [J]. Journal of Chifeng University (Natural Science Edition), 2013, (23): 89-90.

[3] Zhang Xiaojie. An Comparative Study of College Students' Learning Burnout in Physical Education and Sports Training [J]. Journal of Changchun Education College, 2013, (02): 27-28.

[4] Fu Zhiguo, Liu Guozhong. An Analysis of Influencing Factors and Education Countermeasures of College Students' Interest in Physical Education [J]. Journal of Liaoning Teachers College (Natural Science Edition), 2010, (04): 70-71 + 75.

[5] Zhang Na. A Study on College Students' Learning Burnout in Sports Training [J]. Journal of Shenyang Sport University, 2010, (02): 106-108 + 115.

[6] Qiao Xiaowei. A Research of Restraining Factors and Countermeasures of College Students' Physical Exercise Behavior [J]. Modern Science, 2010, (02): 163.

[7] Chen Peihui. A Research of Factors and Countermeasures of Female College Students' Physical Exercise Habits [J]. Journal of Guangdong Polytechnic Normal University, 2008, (06): 127-130. 